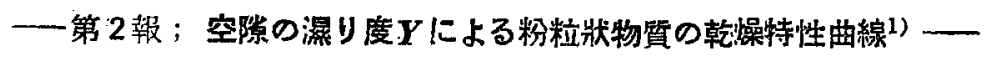

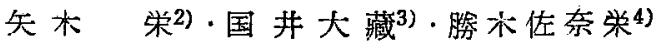

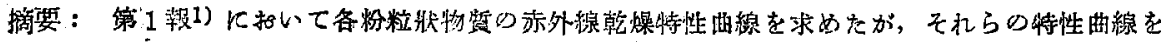

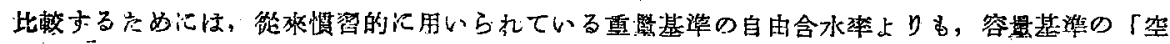

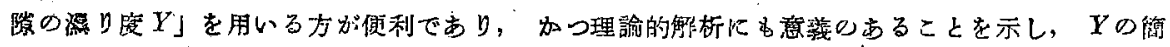

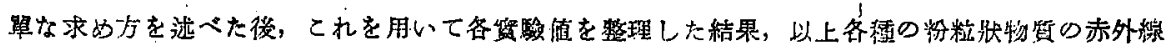

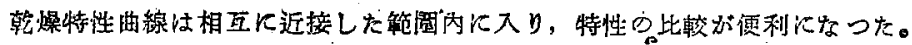

\section{\$1. 䋹 論}

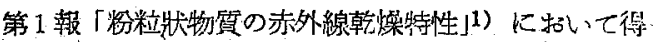

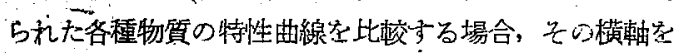
慣習的な重最基淮の自由含水來に取ると，各粒子の夏比

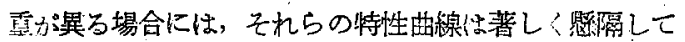

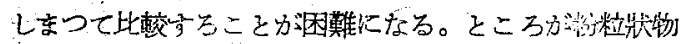

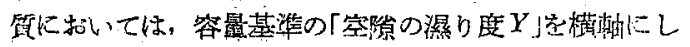
て特性曲線㞭あらわすと，それらの絕刘䇚は盾比重の值 にか人からず大約闰じ筑囲內に入り，限界水分の值 $Y$ 。

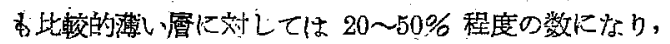
粒子の大きさ，層の厚さに上つて荌動することが認めら れた。以下それについて述へよう。

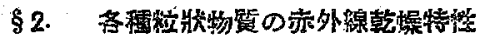

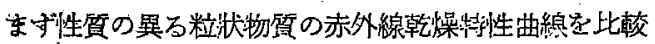

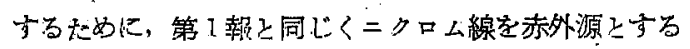

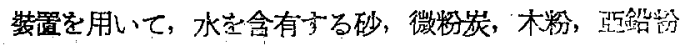

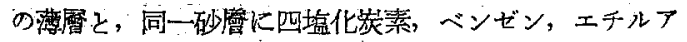
ルニールを浸した場合の赤外線乾燥実驗忘行つた。

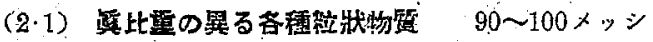

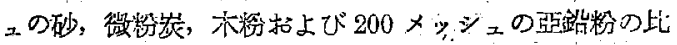

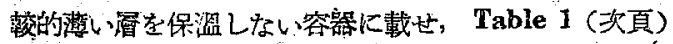

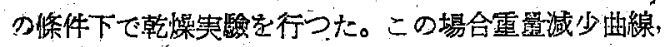

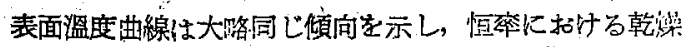

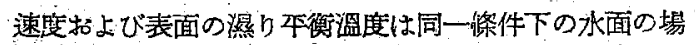
合と大美がない。たら゙しそれら物質の乾燥特性曲線は， その橫朝を慣栶的心用いられている重量基準の自目含水 率即ち $\mathrm{kg}$-water $/ \mathrm{kg}$ Dry Material \% に取つて家らわ゙

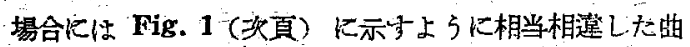
線群亡なる。

從つてからる方法による特性曲線の表示は，同一物質

1) 昭和 25 年 8 月 8 日要埋

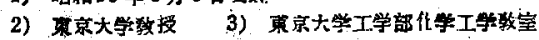

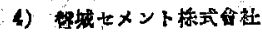

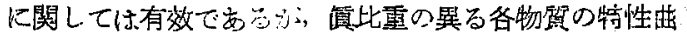
線を比較するためには便利でないとずわ家る。

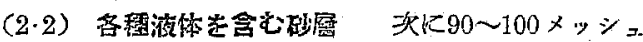
の秒管に，四塩化炭素、ベンゼン、エチルアルュールを

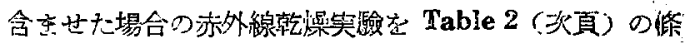
件下で行つた。この結果喜 Fig. 2-A (炏頁) に示した

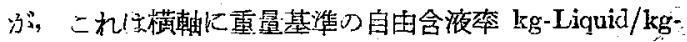

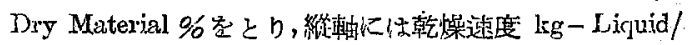

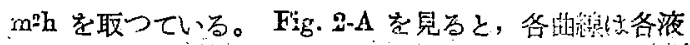
の蒸発潜熱の相湋のために相当異つており，限界含液璃 る。腤近く変化している。

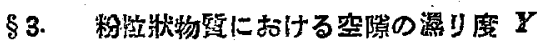

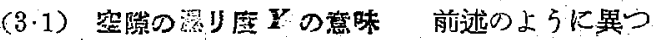
广性質を有する各種の粉粒狀物質や，同じ物望です翼つ

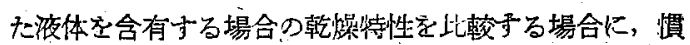
習的就重量基準の自由含水 (液) 率を用いる特性曲線て

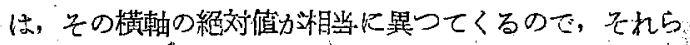

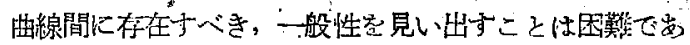

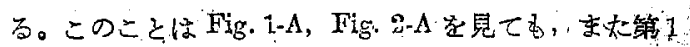
裉の Fig. 10，Fig. 11，Fig. 13 を此校してるかかる。 认㐬乾懆特性曲線の形を洪定士る主要素々して限界含水

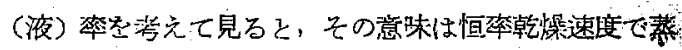

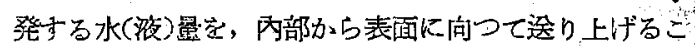
とができなくなる瞬間つ含神水(㳊)量で岁るから，その 值に対しては汾粒体身身の性質よりはむしろそれらによ つて作られる空隙心状態と，その中を水(液)か流埴する

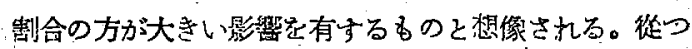

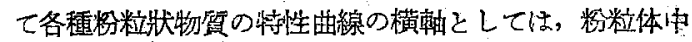

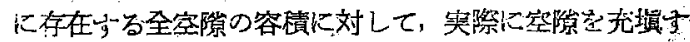
る水(液)分の容棈の割合を取る方か浽当であるように思 われ，唯今はこれを「空知の濕り度 $Y$ 」と名附けるこ と结马。

事実この量基基测として前述した各粉粒狀物質の赤外 

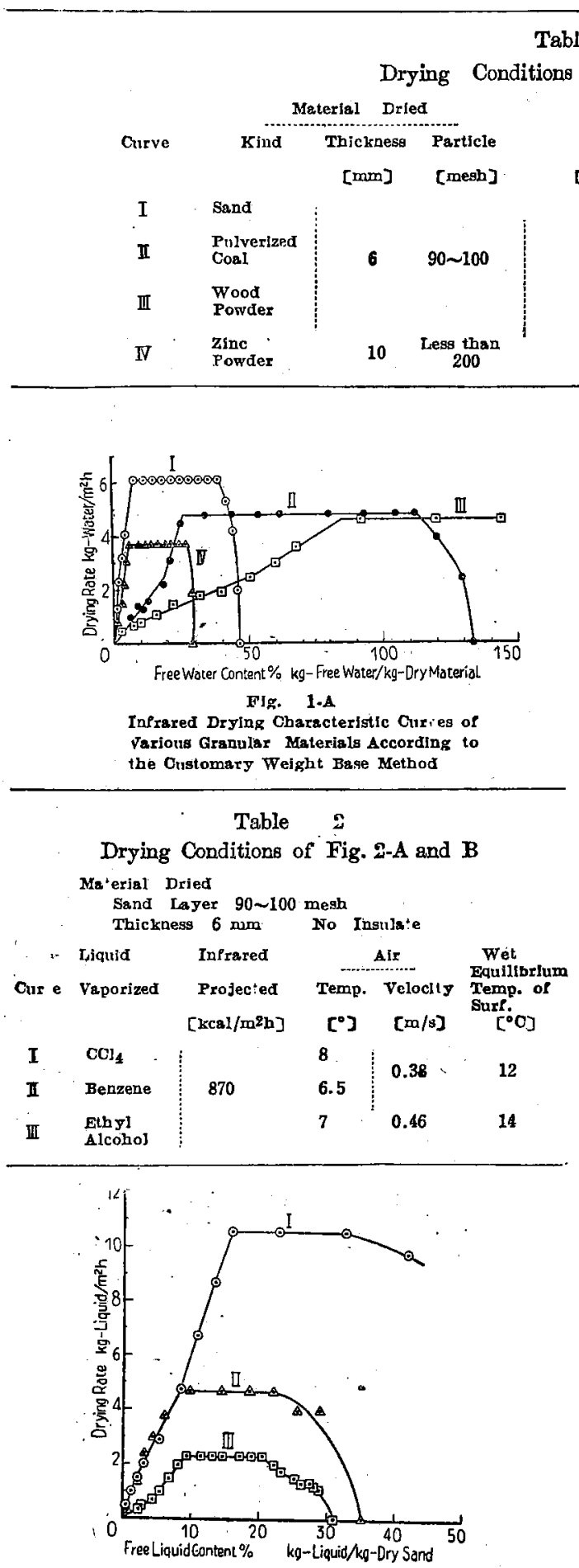

Fig. 2-1 Infrared Dryling Characteristic Curves of Fine Sand Layers Containing Farious Kinds of Liquid According to the Custo-mary Welght. Bage Me hod
Table 1

of Fig. 1-A and B

Infrared

Projected

[lacs $\left./ \mathrm{m}^{2} \mathrm{~h}\right]$

4100

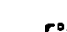

Water Papour

Temp. Water Vapour Pelocity

[ $\left.{ }^{\circ} \mathrm{C}\right]$ [atn] [n/s]

$50 \quad 1.6 \times 10-2 \quad 1.28$

\begin{tabular}{ll:|cc}
4200 & 9 & 1.3 & 0.76 \\
& 13 & 1.4 & 1.34 \\
2700 & 15 & & 0.75
\end{tabular}

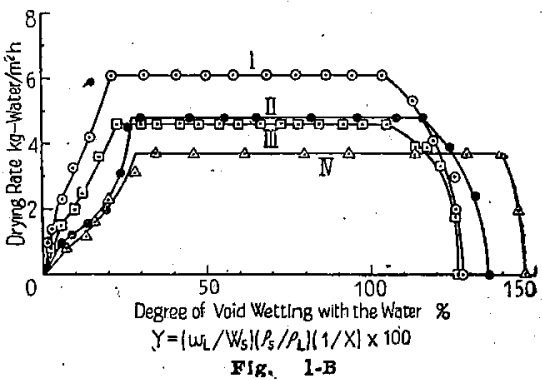

Infrared Drying. Oharacteristic Curvey of Various Granular Ma'erials According to the Volurne-Base Method

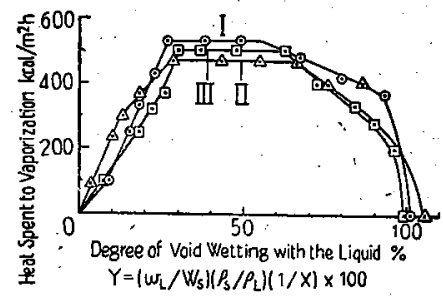

Fig. 2-B Infared Drying Characteristic Cur es of Fine Sand Layers Con:aining Various Kinds of Liquid According to the Volume and Heat-spent Me:hod

線乾燥特性曲線を比較した結果は同一程度の乾燥佟件下 では後述の上うに大略近似した形となり，限界点に拈け る空隙の湂り度 $Y_{0}$ 。粒子の大きさ，試料層厚をが同一 程度の場合は大約同一籁囲內に入る。以上のような取报 (い砂に関して N. H. Ceaglske and O. A. Hougen2) 加? Pexcent Saturation なる表現考行い，ガラス小球に関し $\tau$ O. Krischer und P. Görling3) $\varphi_{0}$ なる式を用いて行つているが，著者らはその他各種

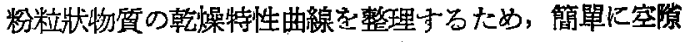
の濕り度 $Y$ を求める污法考考察した。

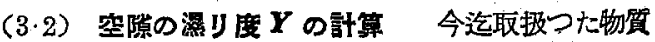
に関して檢討すると，乾幧中殆んど收縮泉さないるの そ，著しく收蛨するるのがある。前者は比較的粒子の犬 きい場合で問題はないが，後者は收縮した狀態にさったる 


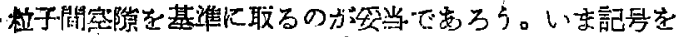

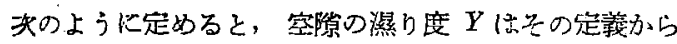
下式で計算でることができる。

\section{記 号}

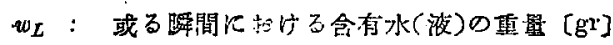

$W_{s}$ ：緜いた物留の重量 [gr]

$\rho_{L}:$ 水 (液) 向靬眼 $\left[\mathrm{gr} / \mathrm{cm}^{3}\right]$

$\rho_{s}$ ：物留粒子の密没 $\left[\mathrm{gr} / \mathrm{cm}^{3}\right]$

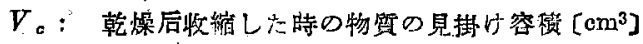

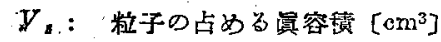

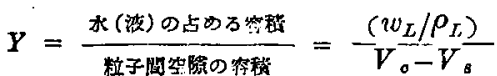

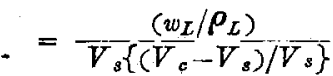

$$
\begin{aligned}
& =\frac{\left(w_{L} / \rho_{L}\right)}{\left(W_{s} / \rho_{s}\left\{\left(V_{c}-V_{s}\right) / V_{s}\right\}\right.}
\end{aligned}
$$

$$
\text { w女 } X=\frac{V_{a}-V_{s}}{V_{s}}
$$

そすれば

$$
Y=\left(w_{L} / W_{s}\right)\left(\rho_{s} / o_{L}\right)(1 / X)
$$

(3.3) 式中 $\left(w_{L} / W_{s}\right)$ は自由含水(液)率であつて, 实

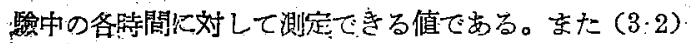

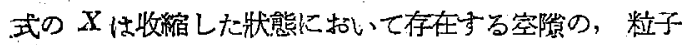

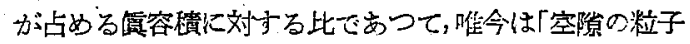
に対する容皘比」と呼ぶことにしよう。普通からっ場合 K用いら虬ている空吵比 (Void Patio) $e$ は

$$
e_{-}=\left(V_{c}-V_{s}\right) / V_{c}
$$

であるから， $X$ と $e$ とは次の関係にある。

$$
e=X /(1+X), \quad \dot{X}=e /(1-\ddot{e})
$$

次項の上与な別の実驗に上り， $\rho_{s}$ と $X$ を求めて括けば

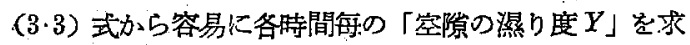
あることができる。

$Y$ の物理的意味は前述のよ5に沿粒狀物質の缹り程度 逄あらおするのであつて，水或は液体て飽和している場 -合には $Y=100 \%$ ，全乾の時は0\%となる。あた乾燥中 收縮与る物質で未ナ乾燥の行われていない狀態や，收縮 しない物質ても表面上に水をたは液の薄層力存在与る狀 態では $Y=130$ とか $150 \%$ とかの值になり，30，50\%は 過剩水 (液)分をあらわすことになる。

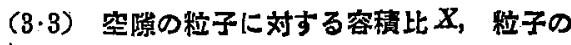

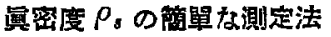

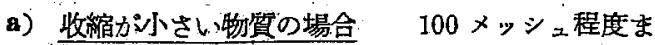
での粒子蟹では，過剩の水分は部に押し出されるの で，普通の含水(液)狀態で既に备粒子は，それ以上自身 ては近接することのできない密集狀熊に近く，從つて乾 橾㭙の收縮は小さい。
办小る粒子曆の場合に前迅心特性值 $X, e, \rho s$ を䉍單 に求方方法を述べよう。

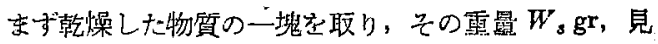

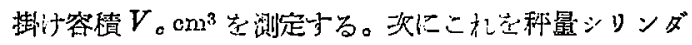
一舟に入れ水添扣して上く攪汼する。親水性フ小さい

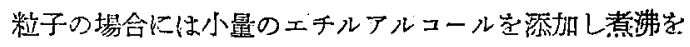

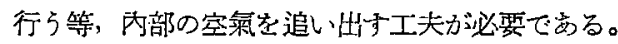

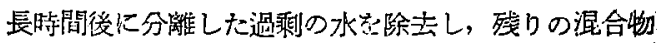
重星崖测定し $W_{c} \mathrm{gr}$ とする。

この特会有自由水分の重毁は

$$
W_{L}=W_{c}-W_{s}
$$

含有自由水分の容積

$$
V_{L}=W_{L} / \rho_{L}=\left(W_{0}-W_{s}\right) / \rho_{L}
$$

從つて固体粒子の供容積は

$$
V_{s}=\ddot{V} \cdot-\dot{V}_{L}
$$

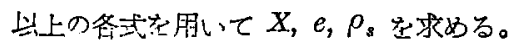

$$
\left\{\begin{array}{l}
X=\left(V_{c}-V_{s}\right) / V_{s}=V_{L} /\left(V_{c}-V_{L}\right) \\
e=\left(V_{c}-V_{s}\right) / V_{c}=V_{L} / V_{0} \\
\rho_{s}=W_{s} / V_{s}
\end{array}\right.
$$

第 1 硍て用いた砂とこの報文で用いている微粉炭，六炭，

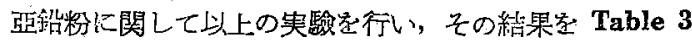
(次面)に示した。

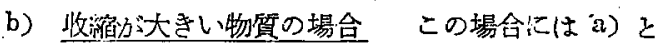

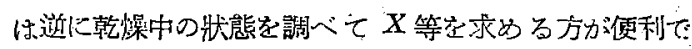

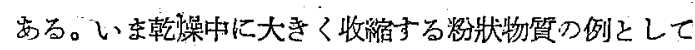

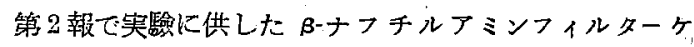
一キと塩基性炭酸マグネシウムを取り，これら肴梁さ約 $10 \mathrm{~mm}$ 直径約 $90 \mathrm{~nm}$ のシャーレに入れ，箱型乾燥器と

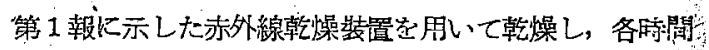

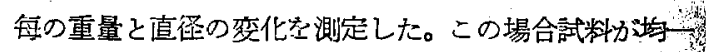

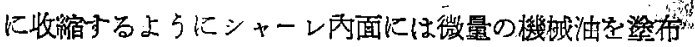
した。いまその一则として赤外線乾焻泩忙よる測定值子

Fig. 3 (次頁) に図示する。すなかち初試料電量は， 誼線的に減少するのに対し，試料直径は 1 時間程度で娍 少を停止し，それ以后は殆んど一定の值に止まる。

さて，いむこれら粉狀物筫の最初の狀態を考えると， Fig. 4 (炊頁) に示すよ5に各粒子は相互に離孔ていて， その間隙に水 (或は液)が充㴁していると仮定できる。

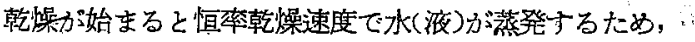
各粒子の間隔は狹くなり，逐にはそれ以上自身て出近力 くことのできない奘態に迄泌集するが，その時まで容䖽

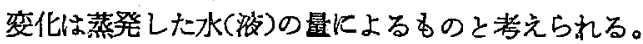

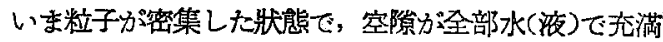
している時の水(液)を標售に取り，てれ以上の水腹)量 家過剩水(液)分と呼ぶことにしよ5。 
Table 3

Calculation of $\rho_{s}, X$ and $e$

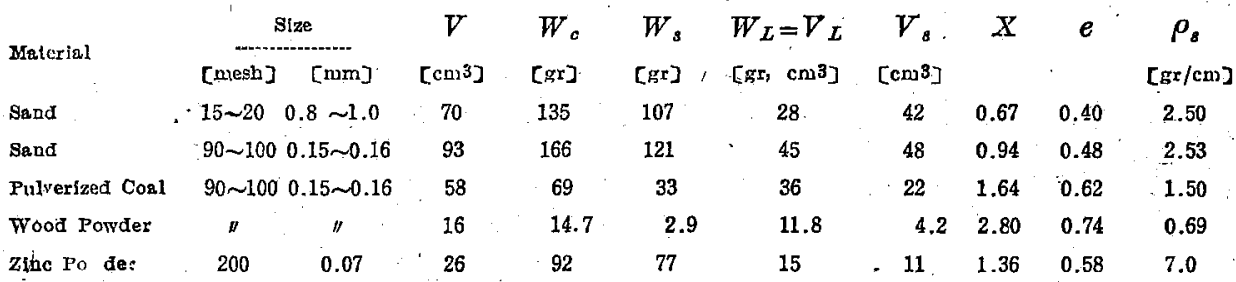

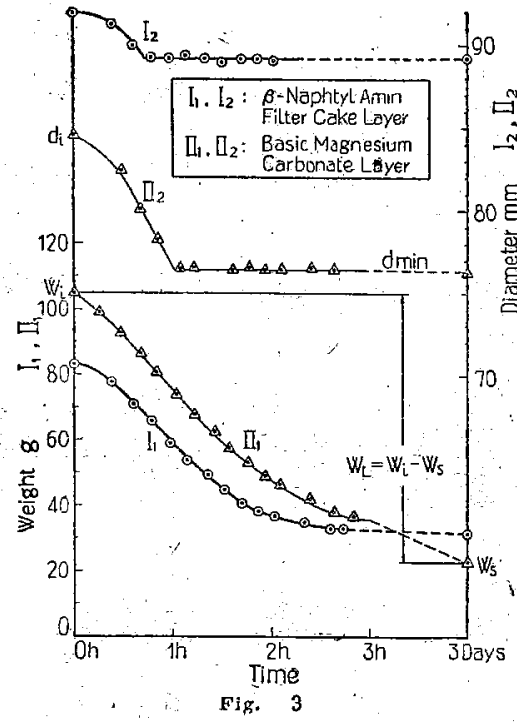

Drsing S ate of Powdery Ma erial
Initial State

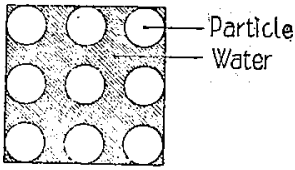

Packing State

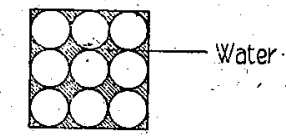

Dry State

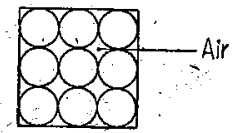

Fig. 4

Model of Drying State in Powdery Ma'erial $d_{i}$ : 最初の試料㨁徑 [ $\left.\mathrm{mm}\right]$

$d_{\text {nin }}$ ：密集状倠の試料直徑 $[\mathrm{mm}]$

$V_{i}$ : 最初の狀態に和ける混合物客積 $\left[\mathrm{cm}^{3}\right]$.

$V_{0}$ : : 密集狀懸の見挂け容栍 $\left[\mathrm{cm}^{3}\right]$

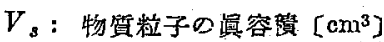

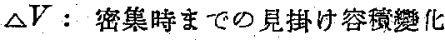
$\left[\mathrm{cm}^{3}\right]$

$V$ : 密集狀態儿於いて合ま机らる最

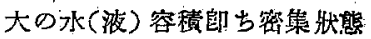

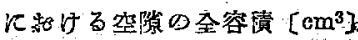

$\rho_{\text {nax }}$ ：最初の狀態に和りる混合物見 接密度 $\left[\mathrm{gr} / \mathrm{cm}^{3}\right]$

$\rho_{L}$ : 水(液) 口虫度 $\left[\left[\mathrm{gr} / \mathrm{cm}^{3}\right]\right.$

$\rho_{s}$ : 固体粒子の娄密度 $\left[\mathrm{gr} / \mathrm{cm}^{3}\right]$

$X$ ：空隙の粒子に對する容敌比

$e:$ 空隙比 (Void Ratio)

$\alpha$ ：渦乘水 (液) 船合
瑶集後は粒子の配列には裂化なく粉体內部の水(液)为: 表面に问つて移動し，蒸発した水(液)の容積に相当する

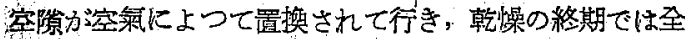
室陵怯悉く空氣で置換されることになる。

以上の考察に上れば，次の三つの仮定定設けることに よりX,e特よび $\rho_{s}$ カ溶易原められる。

仮定

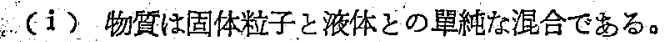

(ii) 最初の狀態に捣てて內部に存在する氣泡仿るす かである。

(iii)：乾燥終了時の溫度に対する平急水(液)分の量は 粒子に比して無視できる程度でする。

いま記是を下のよ5に定めよ5。

$W_{i}$ ：最初の狀態に括ける湜合物重量 [gr]

$W_{8}: \therefore$ 物質粒子の全重量 [gr]

$W_{L}$ ：最初の狀態に扣ける含有水(液)重䭪 [gr]

$\Delta W_{L}:$ 渦剩水 (液) 禹量 $[\mathrm{gr}]$
前述のような实驗にようて $W_{i}, W_{s}, d_{i}^{\prime}, d_{\min }$ を求

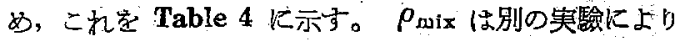
次の平均值岩得た。

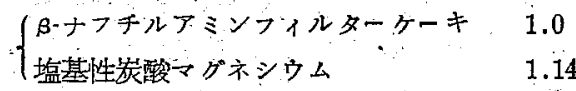

以上の結舆加

$$
\begin{aligned}
& W_{L}=W_{i}-W_{i} \\
& V_{i}=W_{i} / \rho_{\text {mix }}
\end{aligned}
$$

一方粒子の㑯客積は最初の狀態に括いて

$$
V_{s}=\dot{V}_{t}-\left(W_{L} / \rho_{L}\right)
$$

倣に

$$
\rho_{s}=W_{s} / V_{s}
$$

次に收领は等方的と考元てよい加ら

$$
\begin{aligned}
V_{C} & =\left(d_{\min } / d_{i}\right)^{3} \times V_{i} \\
V & =V_{0}-V_{s} \\
X & =V / V_{a}=\left(V_{0}-V_{a}\right) / V_{2}
\end{aligned}
$$




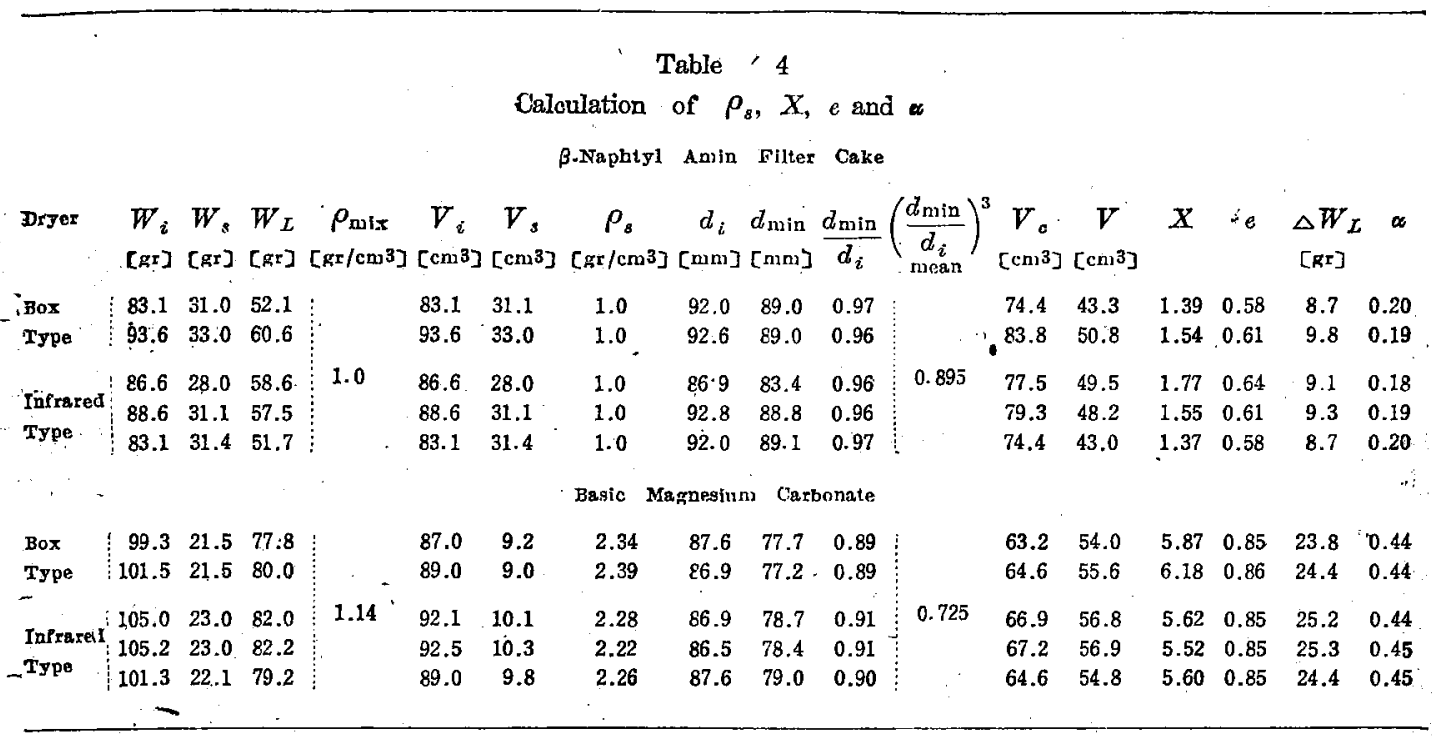

$$
e=V / V_{0}=\left(V_{0} / V_{s}\right) / V_{0}
$$

遗剩水 (液) の $V$ に刘する割合をいとすると

$$
\begin{aligned}
\alpha & =\Delta W_{L} /\left(\rho_{L} \times V\right)=\left(\rho_{L} \times \Delta V\right) /\left(\rho_{L} \times V\right) \\
& =\left(V_{i}-V_{0}\right) / V
\end{aligned}
$$

Table 4 に招いて解に得た実驗結果加以上の各式责 使用して $\rho_{s}, X, e, \alpha$ を計算し，その結果を平均して Table 5に示した。この場合塩基性炭酸マグネシウムの 室隙比eガ 0.85 ，と相当に大きい值示示しているのは， 固体粒子中の結晶水力゙或程度除去され多孔性化するため と考えらけた。

\section{§4. 一空隚の瀑り度 $\boldsymbol{Y}$ による克燥特性の表示}

(4.1) 水を含有する各理粒狀物诈の場合 82 で夷 酹に用いた砂，微粉炭，木粉就よび亞鉛粉の 4 種の粒狀 物䆩は粒度力約 90〜200メ゙ッシュ，寺なわち0.16〜0.07 $\mathrm{mm}$ 程度で, かつ層の愿さる同程度であるが，卡の乾燥 特性曲線を慣習的な重量基準の自由含水率を横軸作用い てあらかすと、 Fig. 1-Aのように極めて異つた曲線群と なつた。そこでいまほ（a）の方法で求めた $X ， \rho_{8}$ 老用

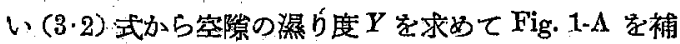
正すると, Fig. 1-B のようになる。この図によれば, 特

$$
\text { Table } 5
$$

Mean Values of Powdery Characteristics

\begin{tabular}{cccccc} 
Material & $\rho_{s}$ & $X$ & $e$ & $\alpha$ \\
{$\left[\mathrm{gr} / \mathrm{cm}^{3}\right]$} & & & \\
B.Naphty1 Anim Filter Cake & 1.00 & 1.54 & 0.60 & 0.20 \\
Basic Magnesium Carbonale & 2.30 & 5.78 & 0.85 & 0.44 \\
\hdashline & & & & \\
\hline
\end{tabular}

性曲線を涣定する要素たる限界水分の值，むなわち限界

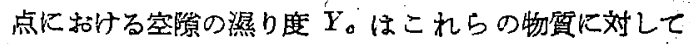
21〜28\%の籍团內に入つてしまう。

李なわち，か今る程度の乾燥速度の場合で, 物質の粒 度, 詹の厚さが同程度の場合には, 限界水分の值 $Y_{\text {。 }}$ は 大約同じ程度になることがわかる。

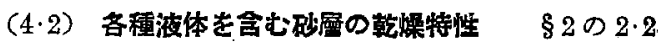
で示したようにこの場合の乾燥特性曲線る相当相互に異 つている。

そこで横軸には前述の $Y$ を取り，縦軸には蒸発に要 した熱量を取つて乾燥特性曲線を图示すると Fig. 巳一B つよらになつて類似した曲線となる。

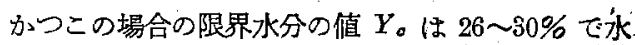
含有する場合と大美がない。

以上の結果によれば，赤外線による恒率乾燥速度は； 殆んどその绦件下の熱量德㒓の速度によつて決定され， ま扎限界水分は主として固体粒子の粒度と層厚さに做存 しているよう思われる。

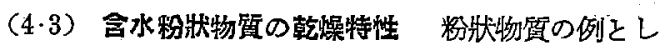
て第 1 報て示した $\beta$-ナラチルアミンフィルターケーキ (染料中間体)，乙塩基性炭酸マグネシウムの赤外線乾燥 特性を調べる。

し、第1 報の各測定值中の限界水分の值を，Table 5 括上 び (3.2) 式在用いて限界点に特ける宾隚の濕り度 $Y_{c}$ に 直しそそのとき幹燥條件とともに Table 6 に表示した。

これによれば $Y_{0}$ は前者の30\%程度に対し後者は50\% 程度で少しく大さい值をとつているがこれは前迅の よらに粒于中の結晶水まで除去されているためと思われ 
Table 6

$Y_{c}$ Obtained by Infrared Drying of Various Granular or Powdery Materials

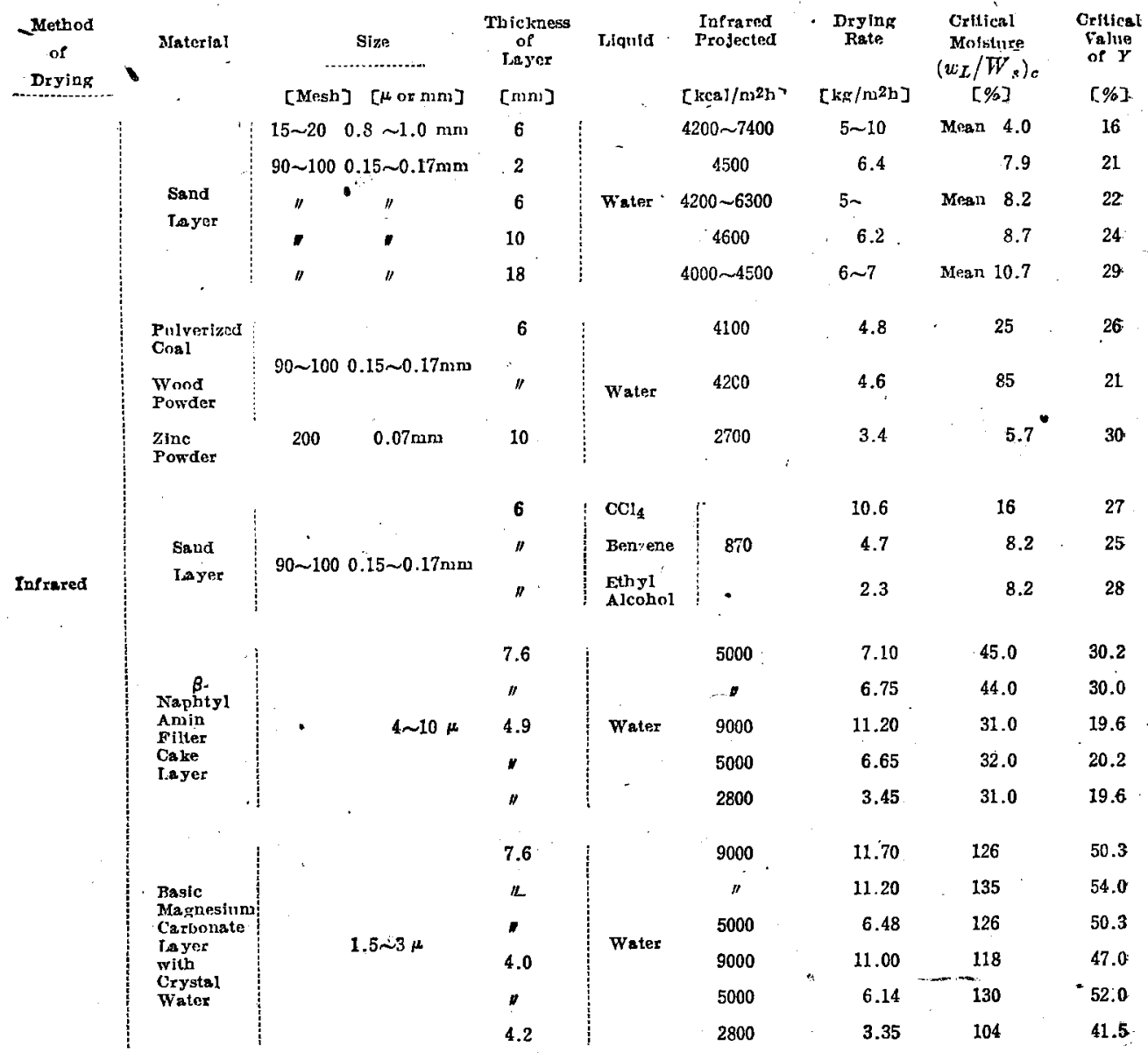

by N. H. Ceaglske and O. A. Hougen3)

Data Obtained

\begin{tabular}{|c|c|c|c|c|c|c|c|c|c|}
\hline $\begin{array}{l}\text { Method } \\
\text { of }\end{array}$ & Material & Size & & $\begin{array}{c}\text { Thickness } \\
\text { of } \\
\text { Layer }\end{array}$ & Liquid & $\begin{array}{c}\text { Air } \\
\text { Tenperature }\end{array}$ & $\begin{array}{c}\text { Drying } \\
\text { Rate }\end{array}$ & $\begin{array}{c}\text { Expression } \\
\text { of } Y\end{array}$ & $\begin{array}{c}\text { Orittcal } \\
\text { Value of } \\
Y\end{array}$ \\
\hline Drystig & & [minl] & & {$[\mathrm{nmm}]$} & & {$\left[{ }^{\circ} \mathbf{C}\right]$} & {$[\mathrm{kg} / \mathrm{nl} 2 \mathrm{~b}]$} & -1. & {$[\%]$} \\
\hline \multirow{3}{*}{ Convection } & \multirow{3}{*}{$\begin{array}{l}\text { Sand } \\
\text { Layer }\end{array}$} & 0.005 & & 25.4 & Water & $53 \sim 66$ & $0.2 \sim 0.3$ & \multirow{3}{*}{$\begin{array}{l}\text { Percentage } \\
\text { Saturation }\end{array}$} & 10 \\
\hline & & 0.016 & & $\|$ & $y$ & $55 \sim 76$ & " & & 10 \\
\hline & & 0.064 & & . & $"$ & $55 \sim 78$ & $0.24 \sim 0.36$ & & $9 \sim 10$ \\
\hline & & y O. Krischer & and & \multicolumn{2}{|c|}{ P. Görling4) } & Data & Obtained & & \\
\hline \multirow{4}{*}{ Conrection } & \multirow{5}{*}{$\begin{array}{l}\text { Glags } \\
\text { Sphere }\end{array}$} & 0.5 & & 10 & Wa'er & - & 0.9 & \multirow{5}{*}{ Trocken. } & 11 \\
\hline & & $p$ & & 20 & " & - & $"$ & & 13 \\
\hline & & $\|$ & & 30 & 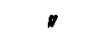 & - & 1.2 & & 15 \\
\hline & & , & & 40 & 。 & - & $y$ & & 17 \\
\hline i & & 0.19 & & $20 \sim 40$ & - & - & $0.25 \sim 0.4$ & & $9 \sim 20$ \\
\hline
\end{tabular}


る.

(4.4）各乾蜗條件と $\boldsymbol{Y}_{\text {。 }}$ 以上の諸結果の比較を便 Kするために，各粉粒狀物質の赤外線乾焻條件の主なる のと, 限界点に括ける空隐の濕り度 $Y_{0}$ とをまとめて Table 6 に表示した。

な詁比輘のため N. H. Ceaglske and Hougen2) 拈よ び O. Krischerer und P. Görling3)に上つて得られた結果 から $Y_{0}$ を求めて Table 6 K附記した。

この表を見ると, 恒率乾燥速度が $2 \mathrm{~kg} / \mathrm{m}^{2} \mathrm{~h}$ 以上の赤 外線䠹燥の場合の限界水分の值は, 重量基準つ限界含水 秦にするこ 4,0〜155\%をで拚つているが，Y、にすると 16〜54\% の間に集つで比較するのに便利となる。な特 Ceaglske おd: U゙ Rischer のデータでは $Y_{c}$ が 10〜15\% で上の值上りは小さい。これは恒率乾懆速度が0.2〜0.9 $\mathrm{kg} / \mathrm{m} 2 \mathrm{~h}$ 程度の小さい值でるるためで，前述の場合の第 2 段限界含水率の値に相当しているるのと考えられる。

§5. 結 び

以上の実驗よりまきらかになつた事頂を要䄪する。

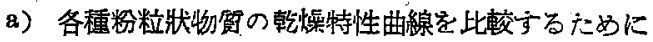

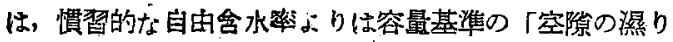
度 $Y$ 」を用いる方が便利である。粒子が $2 \mu \sim 1 \mathrm{~mm}$ の範 囲にわたる薄層の赤外線乾燥実驗では，限界における值
Y。は16〜50\%の範囲に入つた。

b) $Y$ を求めるためには（3.3）式を用い杂ばよく， またそれに必要な譛值ば3.3の方法で簡單に求めること ができる。

c）蒸発潜熱の異る液体を含有する粉粒物質の特性曲 線は，橫軸を「空吵の濕り度 $Y$ 」に取り，縱軸定蒸発に 要した熱量に取る万方便利である。

d）第 1 報の結果によれい゙，含水固体粒子上り成る物 質D恒率乾燥速度, 烝り就よび乾き平衡溫度は或る程度 理論的に予知でき台。さらに表面溫度方濕り平衡溫度少

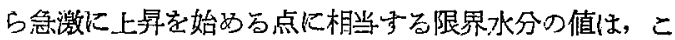
の齿文に示すごとく薄層に対しては大約甬知できる。從

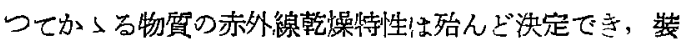
置設訫上極めて便利となる。殊に溫度に敏感な物質に対 しても, 赤外線による急速乾燥裝置の設計が可能となる ように思われる。

\section{琴考交裤}

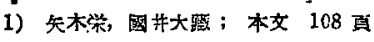

2) N. H. Ceaglske and O. A. Hougen ; Ind. kng. Chem. 29 805 (1937)

3-4) O. Krischer und P. Görling ; P. D. I. Verfahrentechni * $1936 \sim 40$ \& 140

\title{
Infrared Drying Characteristics of Granular or Powdery Materials
}

- (Studies on Infrared Drying I) -

\author{
Sakae Yagi and Daizo Kunii \\ - University of Tolryo
}

In order to study the infrared drying Characteristics of granular or powdery materials, two. kinds of sand layer, coarse and fine, porcelain clay layer, two kinds of dyestuff layer, pow- dery and pasty, and basio magnesium earbonate layer were dried using a infrared projector with electric heating wire which could deliver as much intensity as $2000 \mathrm{koal} / \mathrm{m}^{2} \mathrm{~h}$.

Then, a theoretioal treatment of infrared vaporization from the free water surface was proposed and compared with the experimental results.

Conclusion

a) In the constant rate period, the drying state of these materials are almost same with the vaporizing state of free water under the same infrared drying conditions, except the case of the pasty dyestuff layer:

Therefore, it becomes possible to predict theoretically the drying ryte of these materials at the constant rate period.

b) In case of high inf rared drying; the humidity and the air velocity, within the practical region, have only small ef fects on the drying rate and other drying characteristios. 
o) Critical water content of these imaterials are almost congtant despite the variation of the inf rared intensity.

d) In case of infrared drying of these materials, surface temperature reaches two kinds of equilibrium value, i. e. wet equilibrium temperature and diy one respectively, which can be calculated approximately.

\section{Infrared Drying Characteristic Curves of Some Granular or Powdery Materials Modified with “Degree of Void Wetting $Y$ "}

- (Studies on Infrared II)

Sakae Yagi, Daizo Kunii and Sanae Katsuki

University of Tokso

When the drying Characteristic euves of various granular or powdery materials are compared together, it becomes more conveniement to use the volume-base "degree of roid wetting $Y$ " as the abscissa of these curves than to use the weight-base "free water content."

So in this paper, the methods to obtain $Y$ are described, and after modifying the characteristic curves obtained in authorg' experiments, all of them come into almost same region.

Since the value of critical moisture can be predicted from these results for comparatively thin layers of granular or powdery materials, adequate design of infrared dryer for even the heat-sensible materials is considered to be possible.

\section{化学機械 15 虽-4號丙容予告}

(讙

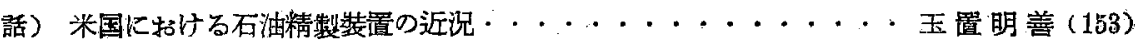

(報

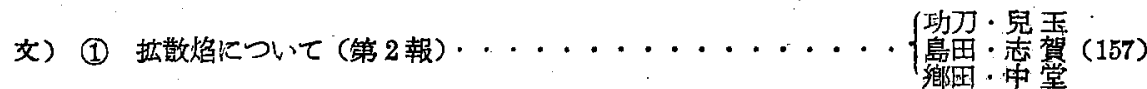

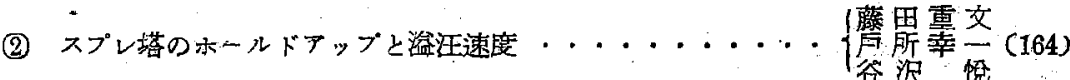

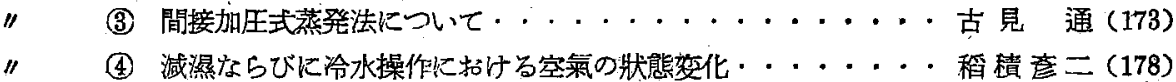

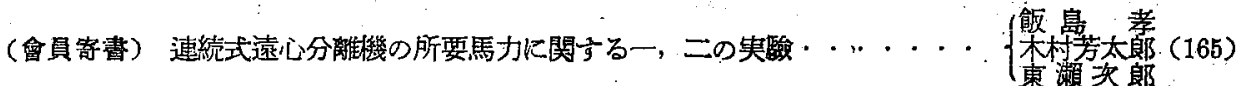

(交献紹介) 化学工学文献一Chemical Engineering Progre⿰氵 46 No. 7 12 (1950)

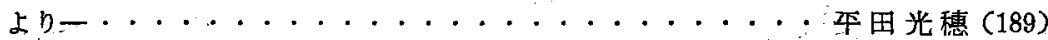

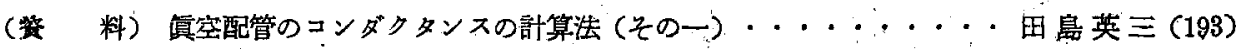

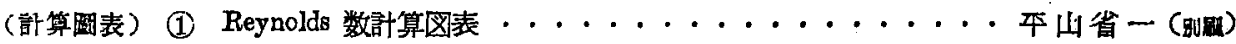

